\title{
TECHNICAL NOTE \\ A NEW, VOLUNTEER-BASED, COST EFFECTIVE METHOD FOR ZOOLOGICAL MAPPING: THE PHOTO IDENTIFICATION OF FRESHWATER CRAYFISH (CRUSTACEA: DECAPODA) SPECIES AND THE IMPORTANCE OF VOLUNTEERS IN CRAYFISH RESEARCH
}

\author{
M. PUKY
}

Hungarian Danube Research Station of the Institute of Ecology and Botany, Hungarian Academy of Sciences, 2131 Göd, Jávorka S: u. 14., Hungary. E-Mail: h7949puk@ella.hu

Reçu le 23 juin 2005

Received june 232005

Accepté le 23 janvier 2006

Accepted january 23, 2006

\begin{abstract}
The publication of the European Crayfish Atlas within the framework of the CRAYNET programme is a major breakthrough in Decapoda mapping in Europe. The current data base contains information from approximately $60-70 \%$ of the $50 \mathrm{~km} \times 50 \mathrm{~km}$ squares covering the continent. A new method to improve this situation further is the use of photo identification involving volunteers in the collection of distribution data. The crayfish identification ability of two potential user groups, astacologists and biology teachers/students, was tested using the questionnaire given in Figure 2. One picture (Astacus leptodactylus male) was correctly identified by everyone, the others were recognised by $59-94 \%$ (astacologists) and $30-88 \%$ (non-crayfish specialised biology teachers and students). The first European Decapoda photo identification survey proved that the necessary expertise exists in the continent to determine crayfish species from pictures and also that the quality of the pictures is less important than the presence of key details. Photo identification is a low cost and environmental-friendly approach but it also needs special considerations. Volunteers need to be supported in several ways, such as by providing precise and interesting educational material in an easily understandable language describing e.g. the key parts of the body to photograph. However, the general use of digital cameras and even mobile phones/cameras and the Internet is an effective way to launch such surveys as it gives, on one hand, an opportunity for the specialists to check, and if necessary correct, the field identification of less experienced people and, on the other hand, it provides a much larger data base than what is available now by using the data collected by students, conservationists, scouts or other volunteers.
\end{abstract}

Key-words: crayfish, Decapoda, methodology, mapping, education, conservation. 


\section{NOTE TECHNIQUE \\ UNE NOUVELLE MÉTHODE ÉCONOMIQUE, BASÉE SUR LE VOLONTARIAT, POUR LA CARTOGRAPHIE ZOOLOGIQUE : IDENTIFICATION DES ÉCREVISSES (CRUSTACEA, DECAPODA) D'APRÈS PHOTOS, ET IMPORTANCE DES VOLONTAIRES DANS LA RECHERCHE SUR LES ÉCREVISSES}

\section{RÉSUMÉ}

La publication de l'atlas des écrevisses d'Europe dans le cadre du programme CRAYNET est une contribution importante pour la cartographie des Décapodes en Europe. La base de données associée contient des informations sur environ 60-70\% des mailles UTM de $50 \mathrm{~km} \times 50 \mathrm{~km}$ couvrant le continent. Une nouvelle méthode permettant l'amélioration de cette situation consiste en l'utilisation de photos fournies via la mobilisation de bénévoles réunissant les données de distribution. La capacité d'identifier les écrevisses de deux groupes, les astacologistes d'une part, et les enseignants et étudiants en biologie d'autre part, a été testée en utilisant le questionnaire de la Figure 2. Une photo (Astacus leptodactylus) a été correctement identifiée par tous et les autres photos par respectivement $59-94 \%$ des astacologistes et $30-38 \%$ des enseignants et étudiants en biologie mais non spécialistes des écrevisses. Ce premier test d'identification de décapodes d'Europe d'après des photos montre que l'expertise existe en Europe pour l'identification des espèces d'écrevisses Ce test montre également que la qualité des images est moins importante que la présence de détails judicieusement choisis. L'identification par photo est peu coûteuse et respecte l'environnement mais elle nécessite le respect de contraintes spécifiques. Les bénévoles doivent être aidés de différentes façons, en particulier par la fourniture de supports pédagogiques facilement accessibles et décrivant les éléments clés qui doivent figurer sur la photo. Ainsi, l'utilisation à grande échelle de photos numériques et même de photos prises à l'aide de téléphones portables associés à l'internet est une façon efficace de réaliser de tels inventaires. Ceci donne aux spécialistes la possibilité de vérifier et éventuellement de corriger l'identification de terrain des personnes moins expérimentées; et d'autre part ceci permet en outre de constituer des bases de données plus fournies que celles habituellement obtenues par les données collectées par les étudiants, les protecteurs, les scouts ou autres bénévoles.

Mots-clés: écrevisses, Décapode, méthodologie, cartographie, éducation, conservation.

\section{INTRODUCTION}

A methodological shift towards environmental-friendly and cost effective methods often including volunteers is becoming more important at the beginning of the 21 st century especially in conservation projects. Besides possible biases of some traditional methods due to their invasive nature, such as clipping digits for marking individuals, and the ethical problems they pose (see, for example, MAY, 2004; FUNK et al., 2005), new methods are also of importance from an educational aspect and in some cases they are also applicable in habitats where monitoring is difficult, such as large rivers and floodplains. New methodology has been successfully applied for several animal groups in different continents, such as acoustic night canoe surveys over the Rio Grande in the US for anurans (JUNG et al., 2002), night spotlight counts of Crocodylus siamensis, a globally critically endangered species in Vietnam (POLET et al., 2002), using the light-reflecting characteristic of crocodile eyes, which was more efficient than a radio collar method applied earlier, and the acoustic monitoring of Megaptera novaeanglidae in the US (CLARK and CLAPHAM, 2004) and Loxodonta africana in Namibia (PAYNE et al., 2003), i.e. listening to the sounds of large mammals both in the ocean and in dense tropical forests under conditions where they are difficult to count with any other method. 
An analysis of methodology used in the publications of the Craynet meeting at Kilkenny, Ireland, a representative conference of European astacologists in 2003 (REYNOLDS, 2003), demonstrated that a large variety of methods has been applied in the study of this animal group in Europe in the 21st century (Figure 1). Some publications also reported information collected from amateur biologists, such as fishermen, managers and other stakeholders.

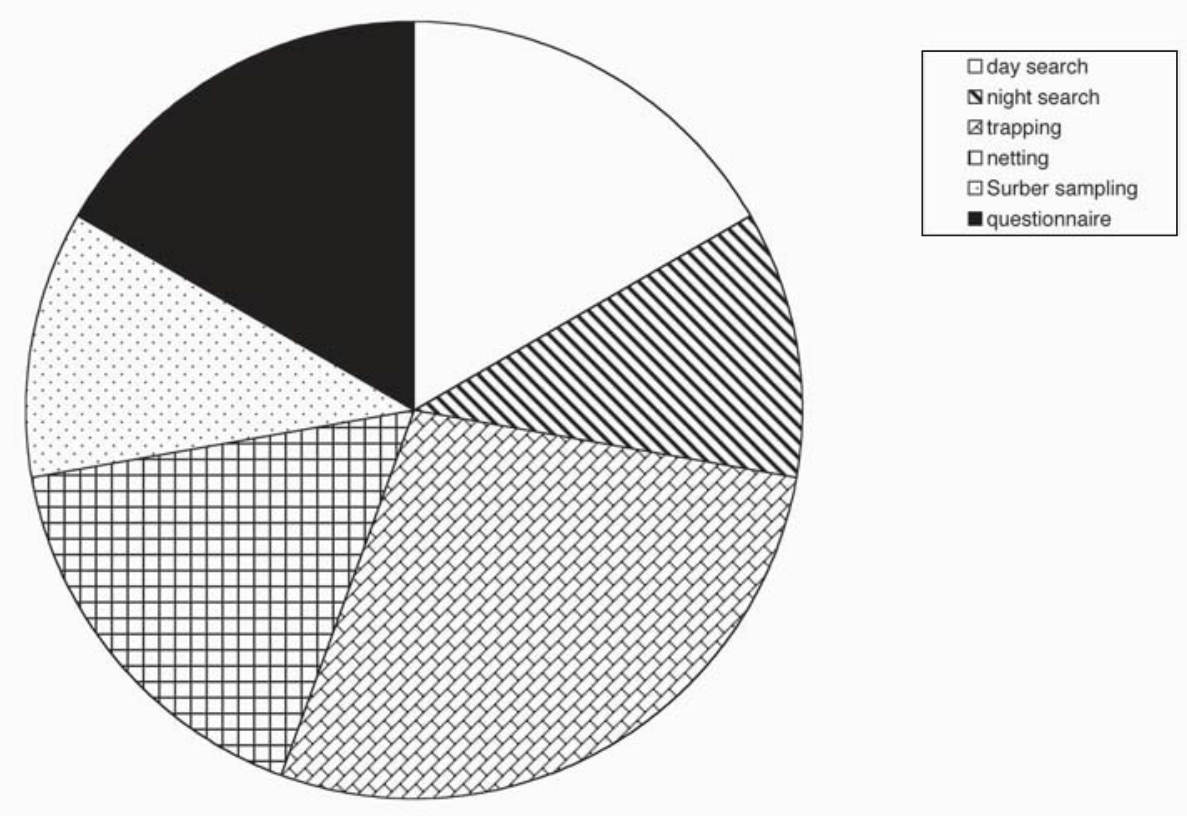

\section{Figure 1}

Relative frequency of sampling methods applied in papers describing field methods presented at the first CRAYNET conference (CHANGEUX, 2003; D'AGARO et al., 2003; DEMERS et al., 2003; FÜREDER et al., 2003; LYONS and KELLY-QUINN, 2003; MAGUIRE et al., 2003; MARTÍNEZ et al., 2003; PEAY, 2003; STEBBING et al., 2003) in Kilkenny, Ireland, June, 2003 (note that in several studies more than one method was used).

\section{Figure 1}

Fréquences relatives des méthodes d'échantillonnage d'après les communications décrivant des méthodes de terrain présentées à la première conférence CRAYNET (CHANGEUX, 2003; D'AGARO et al., 2003; DEMERS et al., 2003; FÜREDER et al., 2003; LYONS and KELLY-QUINN, 2003; MAGUIRE et al., 2003; MARTÍNEZ et al., 2003; PEAY, 2003; STEBBING et al., 2003) à Kilkenny, Irlande, Juin 2003 (noter que plusieurs études comportent l'utilisation de plus d'une méthode d'échantillonnage). 
The publication of the European Crayfish Atlas within the framework of the CRAYNET programme, which is a unique development in this field, however, also indicated that more efforts should be put into mapping, as the current data base consists of information from approximately $60-70 \%$ of the $50 \mathrm{~km} \times 50 \mathrm{~km}$ Universal Transverse Mercator (UTM) squares covering the continent (Patrick HAFFNER, pers. comm.). This is similar to the status of information for some other groups, e.g. reptiles (GASC et al., 1997) but it also indicates that further work is needed to get a more precise overview of the continental distribution of decapod species. However, it is usually difficult to get support for such inventorisation even if it is a necessary basis for many further studies. Also, the number of specialists is limited and most methods are time-consuming, which seriously limits the area which can realistically be surveyed by professional biologists. Besides, there is a clear difference in knowledge on crayfish between individual countries (REYNOLDS and PUKY, 2005) and the collection of more crayfish data is as desirable as the involvement of more people and the improvement of public knowledge. Good quality, accurate and detailed identification keys (e.g. HERMAN, 2004) and active environmental societies such as the crayfish-oriented Action Flusskrebse help this process (for an overview see PUKY et al., 2002) but there is still a lot to do in this field.

One approach to overcome the difficulties outlined above and collect information from previously unknown areas is the involvement of volunteers and the use of photography for crayfish species identification, which is a low cost approach but needs special considerations. This article describes the method, its possible use, advantages and limitations, and also includes initial data on its use.

\section{MATERIAL AND METHODS}

The actual description of photo identification is very simple, i.e. the determination of a species from a picture. Well-shot Decapoda photos can show some morphological characters that can make proper species (in some cases even sex) identification possible even if not all species specific characters can be presented in a single picture. The frequent use of digital cameras allows the building of many such potential data sources e.g. at angling clubs, but no survey has tested the ability of biologists to use this resource for scientific purposes. With European freshwater crayfish species the first such attempt was made at the Florence conference of CRAYNET in May 2005, where professionals were asked to determine four individuals from the pictures provided (Figure 2). To help correct identification, they were also supplied with a short description of the localities the pictures were taken at (for details, see Figure 2), which also carries additional information helping to decide if the first determination was correct. For methodological considerations country of origin and names of participants were not asked for, as the reason for making the survey was to decide if it is possible for most professionals to determine crayfish species from pictures and not the comparison of knowledge between different individuals, age groups, countries or regions. To get an answer from a group with mixed expertise level, students participating in the meeting were not excluded from the data collection. Another set of crayfish photo identification test was carried in autumn 2005 at Eötvös University, Hungary, where students and teachers were asked to fill out the same questionnaire. All participants had finished their Decapoda studies before they gave answers and in comparison with the special interest group tested at the CRAYNET meeting, they were regarded as representative of non-crayfish specialised biologists.

The picture quality as well as the morphological characters shown are key elements of such identifications. To get a better overview of the importance of these details, the pictures presented contained a good quality shot showing characteristics of an easily-recognisable species (Astacus leptodactylus), a moderate quality shot similarly showing an easilyrecognisable species (Orconectes limosus), a bad quality shot showing no special details but showing the whole animal well (Austropotamobius torrentium) and an excellent quality shot showing neither any special details nor the whole animal well (Astacus astacus). 
Log-linear contingency table analysis (SOKAL and ROHLF, 1981) was performed on the data to reveal if there are significant differences between the two groups tested (astacologists, non-crayfish specialised biologists) as well as between the recognition of the individual pictures using the Statistica 6.0 programme.

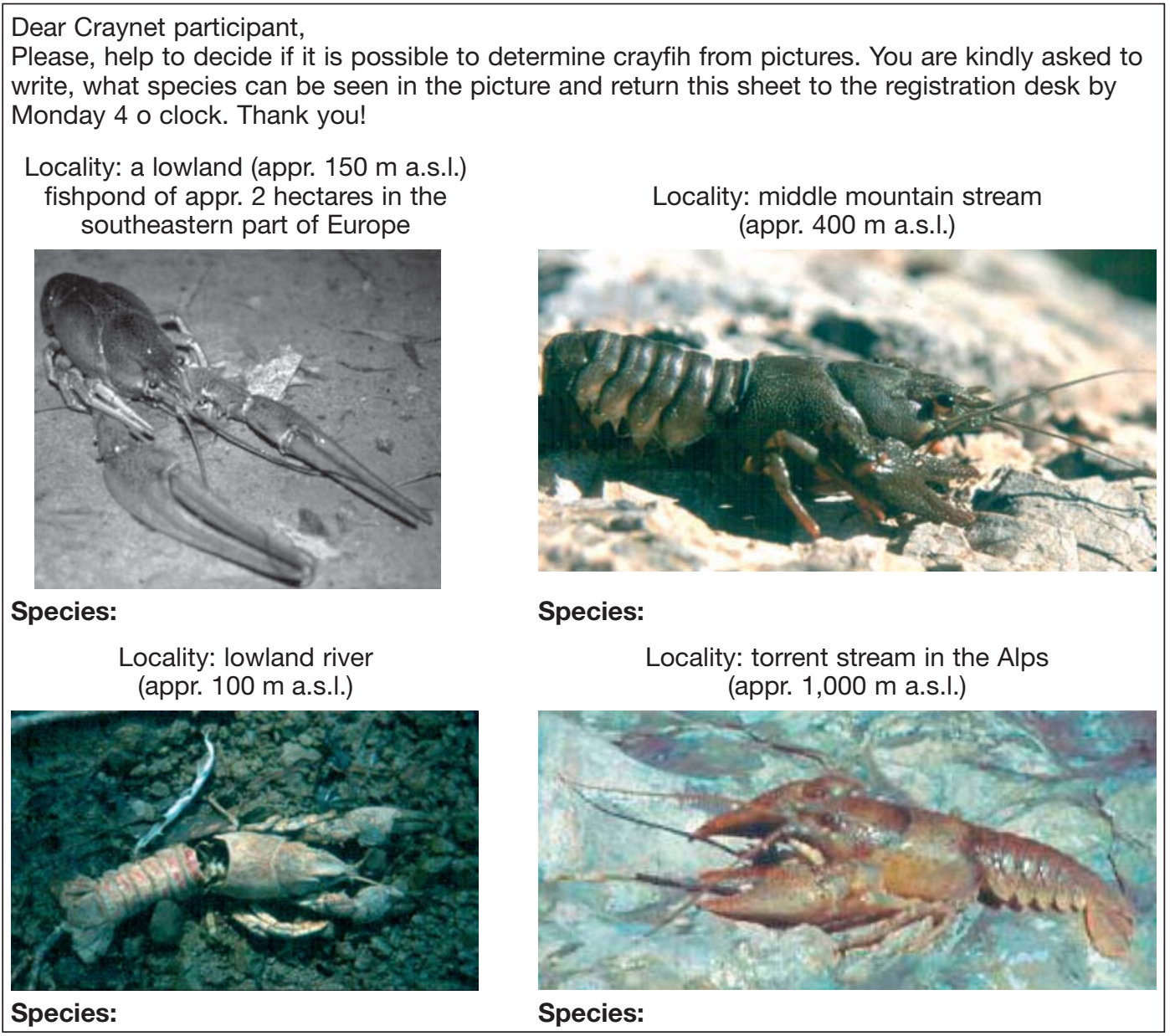

Figure 2

The questionnaire on photo identification of European crayfish species.

\section{Figure 2}

Photos du questionnaire d'identification des espèces d'écrevisses européennes.

\section{RESULTS}

At the 2005 May CRAYNET meeting altogether 19 responses were returned, around one fifth of participants, which is in line with the expected proportions for the personal approach of the method (for details on efficiency differences between public relation methods, see PUKY and VOGEL, 2003) and the dedication of the target group. From Eötvös University 33 responses were received, the participation of the students were certainly affected by the presence of their teachers and as such, not comparable with the proportion of conference participants answering. Figure 3 contains the results for the four pictures used for both groups. The picture of an $A$. leptodactylus male (good quality picture - easily recognisable characteristic) was correctly identified by everyone in both groups. O. limosus (moderate quality picture - easily recognisable characteristic) was still recognised by nearly $95 \%$ and $90 \%$ of astacologists and non-crayfish specialised biologists, respectively. The remaining two pictures showing no obvious species-specific details were identified less successfully. Just over $75 \%$ and $50 \%$ of the two groups recognised $A$. torrentium (bad 
quality picture - no special characteristic but clear body shape), less than $60 \%$ and $31 \%$ A. astacus (excellent quality picture - no special characteristic or clear body shape). The log-linear contingency table analysis revealed a significant difference between astacologists and non-crayfish specialised biologists in their abilities to recognise crayfish from pictures $(\mathrm{G}=4.79, \mathrm{df}=1, \mathrm{p}<0.029)$. Similarly, the detectability of the individual pictures also differed $(G=67.08, d f=3, p<0.00001)$ and there was no freeway interaction, i.e. the same pictures were easy or more difficult to identify for both groups.

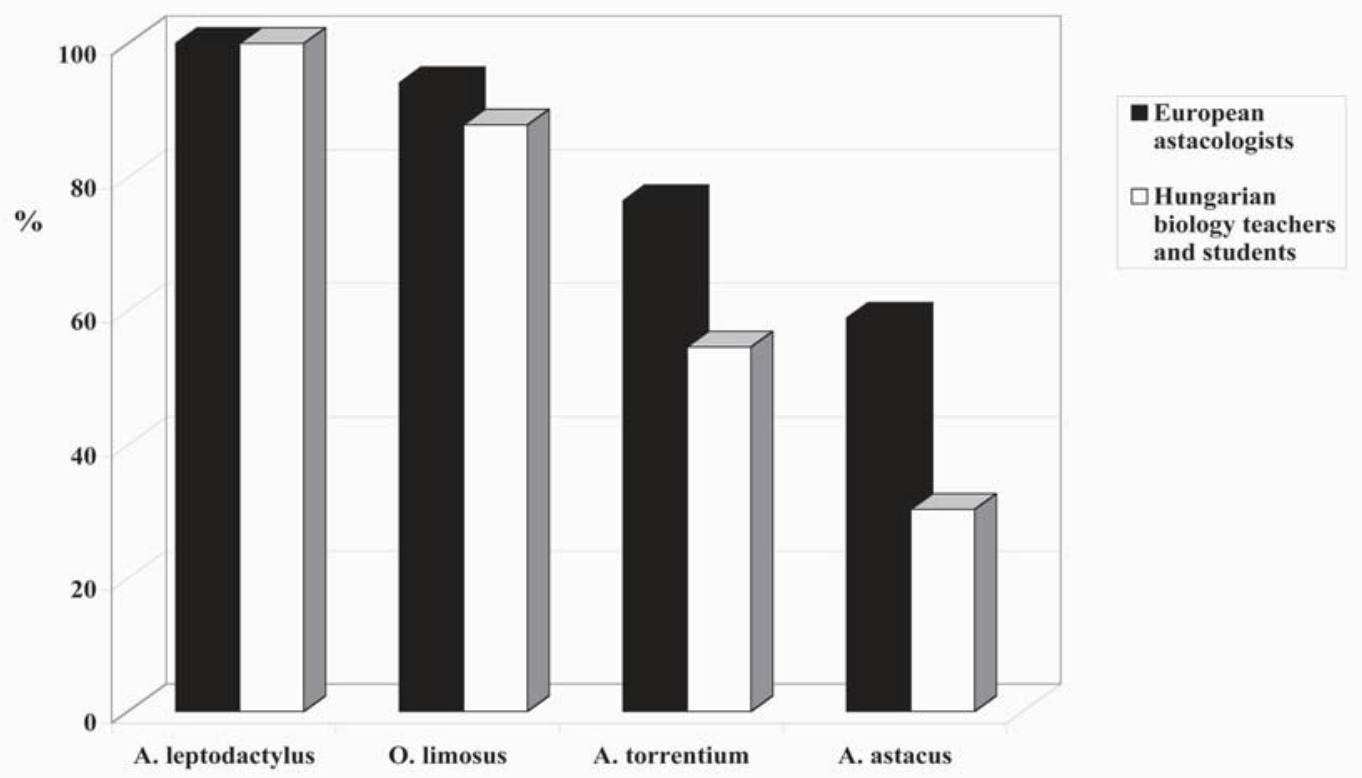

\section{Figure 3}

Levels of successful crayfish species identification from the different photos presented in Figure 2 (solid bar: proportion of correct identification by astacologists; empty bar: proportion of correct identification by non-crayfish-specialised biology teachers and students).

\section{Figure 3}

Taux de réussite d'identification des espèces d'écrevisses à partir des photos présentées dans la Figure 2 (barre remplie : pourcentage d'identification correcte par les astacologistes; barre vide : pourcentage d'identification correcte par les enseignants et étudiants en biologie, non spécialistes des écrevisses).

\section{DISCUSSION}

Volunteer involvement has a long history in the study of some animal groups, such as birds, or through catch records, fish. Others, such as crayfish have not been the focus of such data collection. The first European crayfish photo identification survey proved, however, that the necessary expertise exists in the continent to determine crayfish species from pictures as well. Easily-recognisable pictures might accurately be determined by non-crayfish-specialised biologists but according to the statistical analysis presented here there is a significant difference between them and astacologists in recognising crayfish species from photos. As a consequence, astacologists should play a central role in future 
projects to safeguard data accuracy, especially as in real life situations they can improve their performance further. The expert survey was made away from the laboratories of astacologists, where additional materials, e.g. specimens and photos originating from different geographical areas could be compared with the new pictures to enhance the correctness of their evaluation. Similarly, the associated (e.g. habitat-related) information, which can often be very precise, also helps astacologists more than non-crayfishspecialised biologists in determining which species was caught.

According to the results of the present survey (Figure 3), the quality of the pictures is less important than the presence of key details in the picture. In other words, a picture with lower quality (smaller size, poorly focussed, etc.) might still be a better option than a good quality photo that does not show the main characteristics of the species. The high proportion of correct identifications also demonstrated that similarly to other groups, photo identification has the potential to become a cost-effective, environmental-friendly and volunteer-based method for European decapod species.

To fully realise this potential, teams should be formed to deal with the four basic steps of such data collection: determining the aim and scope of the project together with the target groups; advertising the method to reach the target groups and get support; running the project by processing incoming data, giving feed-back to volunteers and finding contacts in areas from where no or little information has been sent in and making field visits where necessary (e.g. no information exists or something unusual has been reported); evaluating results and building follow-up activities (e.g. management plans for native species, next project in a neighbouring area, etc.) accordingly. At a local level, a national park could organise a photo identification program with the aim of getting an overview of what crayfish live in their territory, inviting an astacologist from a nearby university to produce the necessary materials, e.g. leaflets for the target groups, e.g. anglers, divers and nature conservation school groups in the area. The programme could be advertised through national park premises, local anglers' and divers' clubs, local and regional newspapers and media also using a selected youth group with some experience to show a positive example while the national park provides the necessary funds for these operations. Students from the university and national park staff together could run the project by processing the data, being in contact with volunteers and pinpointing missing areas while the astacologist supervises the determination process and, together with national park officials, determines what further steps should be made, or where site visits are necessary. Evaluation and the working out of future needs should again be a co-operative effort using previously available and new information harmonised with the management plan of the national park.

One of the advantages of this setting is that team members need not be situated at the same organisation as due to technical development these roles can be shared effectively even if co-operating partners live relatively far away from each other. Moreover, as digital cameras and mobile phones with cameras have become common the pictures taken can easily be sent fast anywhere, which might even enable specialists to ask for more specific pictures of the same animals within a very short time. If this approach were to be taken at a national or an international level, however, several considerations should be respected.

Besides the ability of experts to determine crayfish species from pictures, several characteristics of the animals also support its suitability for volunteer work. Decapods are easy to recognise, individuals are a suitable size to pinpoint and handle, they can be handled without harming the animal and are not dangerous for interested people, either. Another advantage of this animal group is that many crayfish species are widespread, not only existing in some remote reserves, and they also occur in different habitat types (DEMERS et al., 2003). They have a hard shell, too, containing distinguishing structures for identification, and thus useful pictures can also be made from remains. 
Another advantage of crayfish is the wide variety and large number of people potentially interested in them. As well as biology students, conservation officials and nongovernmental organisations, schools and scouts and, the largest number, anglers, may also take an interest in these animals. In aiming to reach such a broad target group, the collected information should be kept as simple as possible including date, place, recorder with contact details, and descriptive remarks to accompany the photo(s).

From the organisational point of view there are several further advantages of the proposed method besides low cost. Once started, it is not time consuming but still can yield results from relatively inaccessible regions and it also provides a meaningful project for students/school groups, which is not always easy for teachers to find when taking their class into the field. Communication can be fast and descriptions put on the Internet form an educational material, besides generating the present results, which also creates general interest in the group and can educate future generations on crayfish.

In organising a successful crayfish photo data collection, several important elements should be included. Before getting volunteer involvement in decapod mapping started, participants should have some education in decapod morphology and training for maximal efficiency. A clear aim given in an easily understandable language describing e.g. the key parts of the body of which to take pictures is crucial (e.g. colouration of the claws) as well as the preparation of precise and interesting educational material for further information. A large and regular media coverage preferably supported by well-known personalities would help the project to reach the possible target groups as well as inform the general public. However, to keep volunteers working with this project a help service, positive attitudes to mistakes, and rewards for volunteers (e.g. putting their pictures with their names indicated in the official website) together with regular feed-back is also necessary, which is also a further step in raising the general knowledge of crayfish, and Decapoda in general. As in many European countries there is still a lot to do in this respect (for a detailed analysis see REYNOLDS and PUKY, 2005), photo identification can also serve this educational aim effectively.

Finally, the limitations of photo identification should also be taken into consideration. It can not be used for detailed biological descriptions such as the characterisation of populations, for abundance estimations or disease identification, which should be made clear at the beginning of the project. Besides collecting information on distribution, however, a lot of additional information might be provided e.g. on unusual mortality events, the spreading of introduced species, rare morphs, eg. colour variants such as albinos or blue-coloured individuals. Building on the results of such data collections can thus also serve other aims such as finding out more about disease outbreaks or pollution events.

\section{ACKNOWLEDGEMENTS}

The author wish to thank all participants of the Florence meeting and teachers and students at University Eötvös who completed the questionnaire given in Figure 2, Dr. Julian Reynolds for improving an earlier version of the manuscript, Dr. Catherine SoutyGrosset for the French translation and Dr. Zoltán Botta-Dukát for his help in the statistical analysis.

\section{REFERENCES}

CHANGEUX T., 2003. Changes in crayfish distribution in metropolitan France according to the national surveys performed by the Conseil Supérieur de la Pêche from 1977 to 2001. Bull. Fr. Pêche Piscic., 370-371, 17-41.

CLARK C.W., CLAPHAM P.J., 2004. Acoustic monitoring on a humpback whale (Megaptera novaeanglidae) feeding ground shows continual singing into late spring. Proceedings: Biological Sciences, 271, 1051-1057. 
D'AGARO E., METTULIO R., GIULIANINI P.G., 2003. Vitellogenin and glucose concentrations in the hemolymph of wild and confined crayfish (Austropotamobius pallipes Lereboullet 1858). Bull. Fr. Pêche Piscic., 370-371, 185-192.

DEMERS A., REYNOLDS J.D., CIONI A., 2003. Habitat preference of different size classes of Austropotamobius pallipes in an Irish river. Bull. Fr. Pêche Piscic., 370-371, 127-137.

FUNK W.C., DONELLY M.A., LIPS K.R., 2005. Alternative views of amphibian toe-clipping. Nature, 433, 193.

FÜREDER L., OBERKOFLER B., HANEL R., LEITER J., THALER B., 2003. The freshwater crayfish Austropotamobius pallipes in South Tyrol: heritage species and bioindicator. Bull. Fr. Pêche Piscic., 370-371, 81-95.

GASC J.-P., CABELA A., CRNOBRNJA-ISALOVIC J., DOLMEN D., GROSSENBACHER K., HAFFNER P., LESCURE J., MARTENS H., MARTÍNEZ RICA J.P., MAURIN H., OLIVEIRA M.E., SOFIANIDOU T.S., VEITH M., ZUIDERWIJK A. (eds), 1997. Atlas of Amphibians and Reptiles in Europe. Societas Europaea Herpetologica and Muséum National d'Histoire Naturelle, Paris. p. 496.

HERMAN D., 2004. Les Écrevisses indigènes et exotiques en Région wallonne. Association Theutoise pour l'Environnement, Theux. p. 32.

JUNG R.E., BONINE K.E., ROSENSHIELD M.L., DE LA REZA A., RAIMONDO S., DROEGE S., 2002. Evaluation of canoe surveys for anurans along the Rio Grande in Big Bend National Park, Texas. J. Herpetol., 36, 390-397.

LYONS R., KELLY-QUINN M., 2003. An investigation into the disappearance of Austropotamobius pallipes (Lereboullet) populations in the headwaters of the Nore River, Ireland, and the correlation to water quality. Bull. Fr. Pêche Piscic., 370-371, 139-150.

MAGUIRE I., KLOBUCAR G.I.V., GOTTSTEIN-MATOCEC S., ERBEN R., 2003. Distribution of Austropotamobius pallipes (Lereboullet) in Croatia - past and present. Bull. Fr. Pêche Piscic,. 370-371, 57-71.

MARTÍNEZ R., RICO E., ALONSO F., 2003. Characterisation of Austropotamobius italicus (Faxon, 1914) in a central Spain area. Bull. Fr. Pêche Piscic., 370-371, 43-56.

MAY R.M., 2004. Ethics and amphibians. Nature, 431, 404.

PAYNE K.B., THOMPSON M., KRAMER L., 2003. Elephant calling patterns as indicators of group size and composition: the basis for an acoustic monitoring system. African Journal of Ecology, 41, 99-107.

PEAY S., 2003. Minimising loss of crayfish and habitat during works on watercourses. Bull. Fr. Pêche Piscic., 370-371, 193-207.

POLET G., MURPHY D.J., LAM V.P., MUI V.T., 2002. Crocodile conservation at work in Vietnam: Re-establishing Crocodylus siamensis in Cat Tien National Park. Proceedings of the 16th Working Meeting of the Crocodile Specialist Group of the Species Survival Commission of IUCN. Gainesville, Florida, 7-10 October, 2002. 86-95.

PUKY M., REYNOLDS J.D., GRANDJEAN F., 2002. Education as a key to Decapod conservation. In: SOUTY-GROSSET C., GRANDJEAN F. (eds) Knowledge-based management of European native crayfish. Crayfish special volume 4. Bull. Fr. Pêche Piscic., 367, 911-916. 
PUKY M., VOGEL ZS., 2003. Amphibian mitigation measures on Hungarian roads: design, efficiency, problems and possible improvement, need for a co-ordinated European environmental education strategy. Proceedings IENE Conference 2003, Institute of Nature Conservation, Bruxelles. 1-11.

REYNOLDS J.D., 2003. Irish Craynet meeting. Crayfish News, 25(3), 1-6.

REYNOLDS J.D., PUKY M., 2005. The importance of public education for the effective conservation of European native crayfish. Bull. Fr. Pêche Piscic., 376-377, 553568.

SOKAL R.R., ROHLF F.J., 1981. Biometry. W.H. Freeman and Company, San Francisco. p. 859.

STEBBING P.D., WATSON G.J., BENTLEY M.G., FRASER D., JENNINGS R., RUSHTON S.P., SIBLEY P.J., 2003. Reducing the threat: the potential use of pheromones to control invasive signal crayfish. Bull. Fr. Pêche Piscic., 370-371, 219-224. 